\title{
Effective expression of the green fluorescent fusion proteins in cultured Aplysia neurons
}

\author{
I. Sahly ${ }^{1}$, H. Erez, A. Khoutorsky, E. Shapira, Micha E. Spira* \\ Department of Neurobiology, Institute of Life Sciences, The Hebrew University of Jerusalem, Jerusalem 91904, Israel \\ Received 13 January 2003; received in revised form 14 March 2003; accepted 14 March 2003
}

\begin{abstract}
The green fluorescent fusion protein and its isoforms are extensively used to monitor gene expression, protein localisation and their dynamics in relations to fundamental cellular processes. However, it has not yet been effectively applied to Aplysia neurons that serve as a powerful model to study the mechanisms underlying neuroplasticity. We report here the development of a procedure combining in vitro transcription of mRNA encoding fluorescent-tagged proteins and its subsequent injection into the cytoplasm to image, in real-time, protein dynamics in cultured Aplysia neurones. To illustrate the efficiency of the procedure we report here the visualisation of actin, microtubules and vesicle trafficking. The results presented here introduce a reliable and effective method to express green fluorescent protein (GFP) fusion proteins in cultured Aplysia neurons.
\end{abstract}

(C) 2003 Elsevier Science B.V. All rights reserved.

Keywords: Green fluorescent protein; GFP; mRNA; Actin; Tubulin; Aplysia neurons

\section{Introduction}

The green fluorescent protein (GFP) emits green light when excited by blue light without the use of a substrate and may thus be viewed in living or fixed tissue (Lippincott and Smith, 1997; Tsien, 1998; Baumann and Reyes, 1999; Chamberlain and Hahn, 2000). Since its discovery and isolation from the jellyfish Aequorea victoria (Chalfie et al., 1994), it has been efficiently used to image gene expression, to monitor cellular protein localisation and its dynamics (for review Stearns, 1995; Gerdes and Kaether, 1996; Day et al., 2001; Van Roessel and Brand, 2002). The growing family of fluorescent protein variants enables more sophisticated studies of protein function within living cells (Ellenberg et al., 1999; Periasamy and Day, 1999; Day et al., 2001).

GFP fusion proteins have been used in neurobiological studies as a tracer for individual neurons during development of neuronal networks and as markers

* Corresponding author. Tel.: +972-2-658-5091; fax: +972-2-5637033 .

E-mail address: spira@cc.huji.ac.il (M.E. Spira).

${ }^{1}$ Present address: Institute of Biology, College de France, 11 place Marcelin Berthelot, 75231 Paris Cedex 5, France. for proteins distribution within single neurons in relation to various physiological functions (Spergel et al., 2001).

Aplysia neurons have been extensively used to study the biophysical, cellular and molecular mechanisms that underlie simple forms of behaviour, and in particular the mechanisms underlying short and long-term neuronal plasticity (for review see the Nobel lecture of Kandel, 2001a,b). In addition, cultured Aplysia neurons are extensively used to study the mechanisms of growth cones motility, navigation, regeneration and synaptogenesis (for review see Spira et al., 1996, 2001, 2003; Suter and Forscher, 2000). The relationship between these processes and protein dynamics is mainly based on retrospective immunolabelling of various proteins, microinjections of fluorescent probes and electron microscopy (for example see Bailey and Kandel, 1993; Gitler and Spira, 1998, 2002; Spira et al., 2001; Scheafer et al., 2002).

The studies performed using Aplysia to elucidate fundamental mechanisms underlying neuroplasticity could be significantly facilitated by the use of GFP fusion proteins. Nevertheless, attempts to express GFP fusion proteins in Aplysia neurons were only partially successful. In 1996, Kaang introduced the gene encoding 
GFP using a pNEX derivative vector (Kaang, 1996a,b). The pNEX3 vector was reported as a plasmid fostering the most efficient expression of $\beta$-galactosidase from the lacZ gene in Aplysia neurons. However, the rate of successful expression of GFP following DNA injection of pNEX3-GFP plasmid was low, approximately $20 \%$ (Kim and Kaang, 1998). Furthermore, no significant fluorescent signal was detected in the axon or in the neurites.

Here we report the development of an effective procedure for the expression of EGFP-tagged protein in Aplysia neurones. The method consists of in vitro transcription of mRNA encoding EGFP-fusion proteins and its subsequent intracellular microinjection into the cytoplasm. On-line confocal imaging of EGFP tagged actin, tubulin and EGFP-labelled vesicle used to demonstrate the efficiency of the method.

\section{Materials and methods}

\subsection{Solutions}

\subsubsection{L-15 supplemented for marine species ( $m s L-15$ )}

Leibovitz's L-15 Medium (GibcoBRL, Paisley, Scotland) was supplemented for marine species according to Schacher and Proshansky (1983) by the addition of 12.5 $\mathrm{g} / 1 \mathrm{NaCl}, 6.86 \mathrm{~g} / \mathrm{l} \mathrm{D}(+)$ Glucose $\cdot \mathrm{H}_{2} \mathrm{O}, 3.15 \mathrm{~g} / 1$ anhydrous $\mathrm{MgSO}_{4}, 344 \mathrm{mg} / \mathrm{K} \mathrm{KCl}, 192 \mathrm{mg} / \mathrm{NaHCO}_{3}, 5.7 \mathrm{~g} / \mathrm{l}$ $\mathrm{MgCl}_{2} \cdot 6 \mathrm{H}_{2} \mathrm{O}$ and $1.49 \mathrm{~g} / 1 \mathrm{CaCl}_{2} \cdot 2 \mathrm{H}_{2} \mathrm{O}$. Penicillin, streptomycin and amphotericin B (Biological Industries, Kibbutz Beit Haemek, Israel) were added up to final concentrations of $100 \mathrm{U} / \mathrm{ml}, 0.1 \mathrm{mg} / \mathrm{ml}$ and $0.25 \mu \mathrm{g} / \mathrm{ml}$, respectively.

\subsubsection{Culture medium}

Consists of 5-10\% filtered hemolymph obtained from Aplysia faciata (specimens were collected along the Mediterranean coast) diluted in msL-15.

\subsubsection{Artificial sea water ( $A S W)$}

$\mathrm{NaCl} 460 \mathrm{mM}, \mathrm{KCl} 10 \mathrm{mM}, \mathrm{CaCl}_{2} 10 \mathrm{mM}, \mathrm{MgCl}_{2} 55$ $\mathrm{mM}$, HEPES $10 \mathrm{mM}$, adjusted to $\mathrm{pH}$ 7.6.

\subsection{Cell culture}

Neurons B1 and B2 from buccal ganglia, MCn neurons from the metacerebral ganglion or LUQs from the abdominal ganglion of Aplysia californica were isolated and maintained in culture as previously described (Schacher and Proshansky, 1983; Spira et al., 1993, 1996). Briefly, specimens were anaesthetised by injection of isotonic $\mathrm{MgCl}_{2}$ solution $(380 \mathrm{mM}$ ) into the animal's body cavity. The ganglia were dissected and incubated in msL-15 containing 1\% protease (type IX, Sigma, Rehovot, Israel) at $34{ }^{\circ} \mathrm{C}$ for $1.5-2.5 \mathrm{~h}$. Follow- ing the protease treatment the ganglia were washed with msL-15, pinned and desheated. The identified neurons were manually pulled out along with their original axon with the aid of a sharp glass microelectrode. The neurons were immediately plated in glass-bottom dishes coated with poly-L-lysine (Sigma) containing culture medium. Microinjections were performed $8-42 \mathrm{~h}$ from plating, at room temperature $\left(21-25^{\circ} \mathrm{C}\right)$.

\subsection{Microscopy}

The system used for imaging consisted of an Olympus microscope 1X70 and a BioRad Radiance 2000/AGR-3 confocal imaging system. The objective used was an Olympus planApo $60 \times, 1.4$ NA oil objective. Images of YGFP and EGFP-actin or tubulin shown in this paper were collected by exitation at $488 \mathrm{~nm}$ and emitted fluorescent collected at $500-560 \mathrm{~nm}$.

\subsection{Axotomy}

Axonal transection was performed by applying pressure on the axon with the thin shaft of a micropipette under visual control, as has been previously described (Benbassat and Spira, 1993; Spira et al., 1993, 1996).

\section{Results}

\subsection{Plasmid constructions}

\subsubsection{EGFP-actin construct}

EGFP cDNA was amplified from pEGFP-N1 vector (Clontech) by polymerase chain reaction (PCR) with two specific primers: 5' GGCCATGGTGAGCAAGG3' and $5^{\prime}$ CTTGTACAGCTCGTCCATG3' containing HindIII and SmaI restriction sites, respectively, in their 5 ' ends. The PCR product was digested with HindIII and SmaI and subcloned into corresponding sites of pBluscript II SK (Stratagen). Aplysia actin, (provided by Dr DesGrosiller, Montreal University) was amplified by PCR from pBluscript containing the actin cDNA using two specific primers: 5'ATGTGTGACGACGATGTT3' and 5'TTAGAAGCACTTGCGGTCG3' with SmaI and XbaI restriction sites at their $5^{\prime}$ ends. Following digestion with SmaI and XbaI, the PCR product was subcloned in-frame with EGFP into the previously prepared $\mathrm{pBluscript-EGFP}$ vector linearized with SmaI and XbaI. The EGFP-Actin fragment was then cut out from pBluscript with $\mathrm{ClaI}$ and $\mathrm{XbaI}$ and subcloned into corresponding sites of $\mathrm{pCS} 2+$ vector (Rupp et al., 1994; Turner and Weintraub, 1994). 

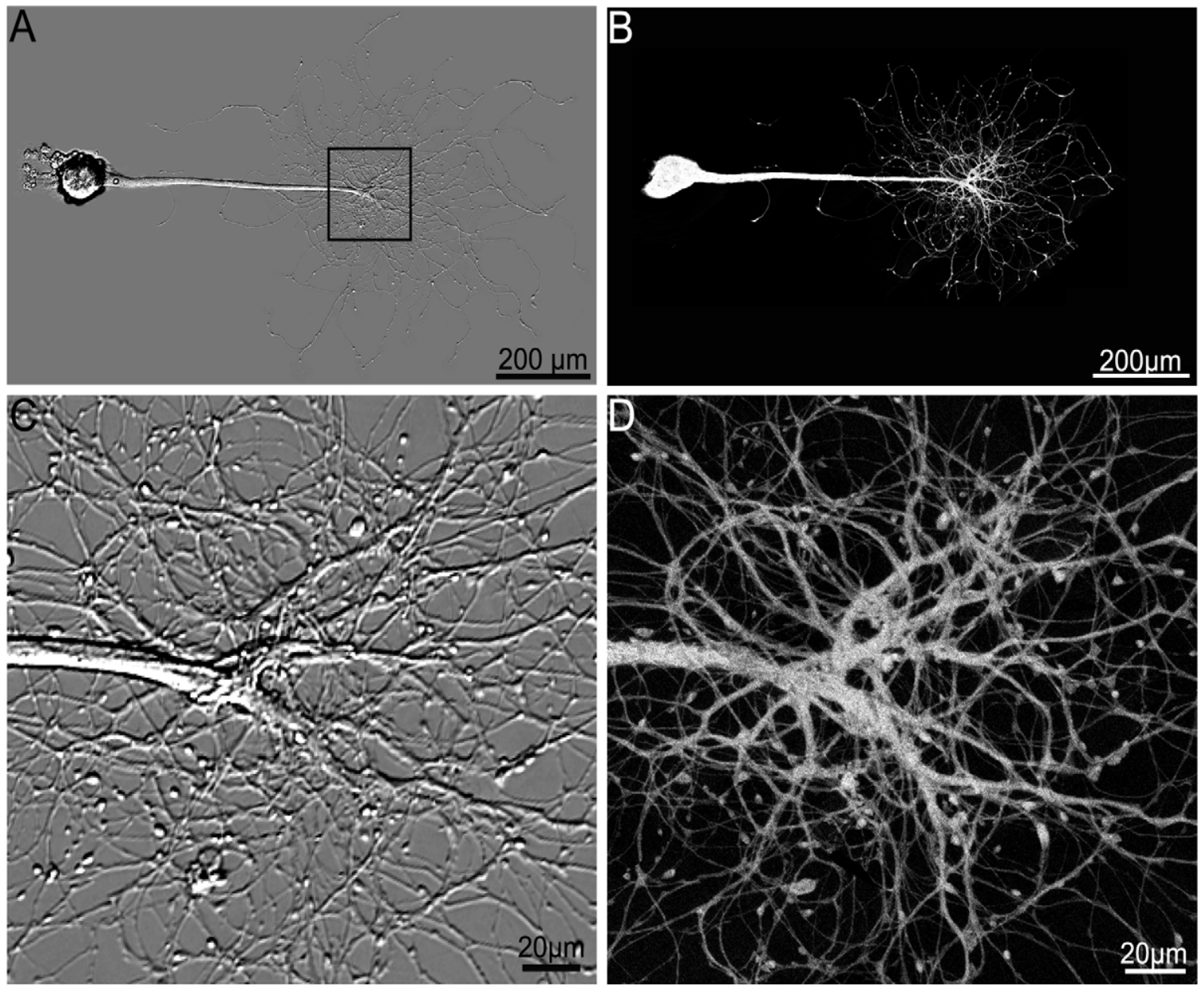

Fig. 1. Expression of EYFP. EYFP mRNA was injected $20 \mathrm{~h}$ before imaging. A and $\mathrm{C}$ are differential interference contrast images of the neuron. C and D are enlargements of the neuronal segment within the rectangle in A. B and D are confocal images. Note that the fluorescent signal is evenly distributed in the axoplasm. The confocal images were produced by the following setting: laser intensity $5 \%$, iris setting 1.6 , gain 100 and Zero offset.

\subsection{Other DNA constructs}

EYFP, EBFP, ECFP and RFP constructs were prepared as described for EGFP-actin. EYFP, EBFP and ECFP cDNAs were amplified, respectively, from pEYFP, pEBFP and pECFP (Clontech) by PCR with the same primers used for EGFP cDNA amplification. The RFP cDNA was amplified from pDsRedl-N1 vector (Clontech) using the primers: $5^{\prime}$ GGCCACCATGGTGCGCTCCT $3^{\prime}$ and $5^{\prime}$ CAGGAACAGGTGGTGGCGG3'.

Aplysia's SNAP-25 cDNA (provided by $\mathrm{Dr}$ W. Sossin, University of Montreal) was amplified by PCR with two primers containing SmaI and SpeI restriction sites and replaced the actin gene from pCS2-EGFP-actin that was excised by SmaI and XbaI.

pCS2-EGFP- $\alpha$-tubulin was prepared from Clontech pEGFP-Tub (cat. 6117-1). This plasmid encodes a fusion protein consisting of EGFP and human $\alpha$ tubulin. The plasmid was digested with BamHI, filled in with T4 DNA Polymerase, digested with NheI and ligated to pCS2 cut by XbaI and SnaBI.

\subsection{In vitro transcription of $m R N A s$}

mRNAs were in vitro transcribed using recombinant transcription system. Briefly, $10 \mu \mathrm{g}$ of the different $\mathrm{pCS} 2+$ constructs were linearized with NotI and purified using DNA clean-up system (Promega). 1-3 $\mu \mathrm{g}$ of linearized DNA were transcribed using RiboMaxsp6 kit (Promega P1280). Typical reaction contain $8 \mu \mathrm{l}$ Transcription Buffer, $8 \mu$ rNTPs mix containing $25 \mathrm{mM}$ CTP, ATP, UTP and $12 \mathrm{mM} \mathrm{GTP,} 4 \mu \mathrm{l}$ of $15 \mathrm{mM}$ Cap analog (Roche 85846029), $1 \mu \mathrm{l}$ rRnasin (Promega N251A), $4 \mu \mathrm{l}$ enzyme mix. Final volume is $40 \mu \mathrm{l}$ and the incubation time is $2-4 \mathrm{~h}$ at $37^{\circ} \mathrm{C}$. RNA purification is done by RNeazy mini kit (Qiagene 74104) and the clean RNA is eluted to final volume of $25-40 \mu \mathrm{l}$ and kept at $-80{ }^{\circ} \mathrm{C}$ until use.

\subsection{Microinjection of $m R N A s$}

The transcribed mRNAs were pressure injected into the cytoplasm of cultured Aplysia neurons 8-48 h after 

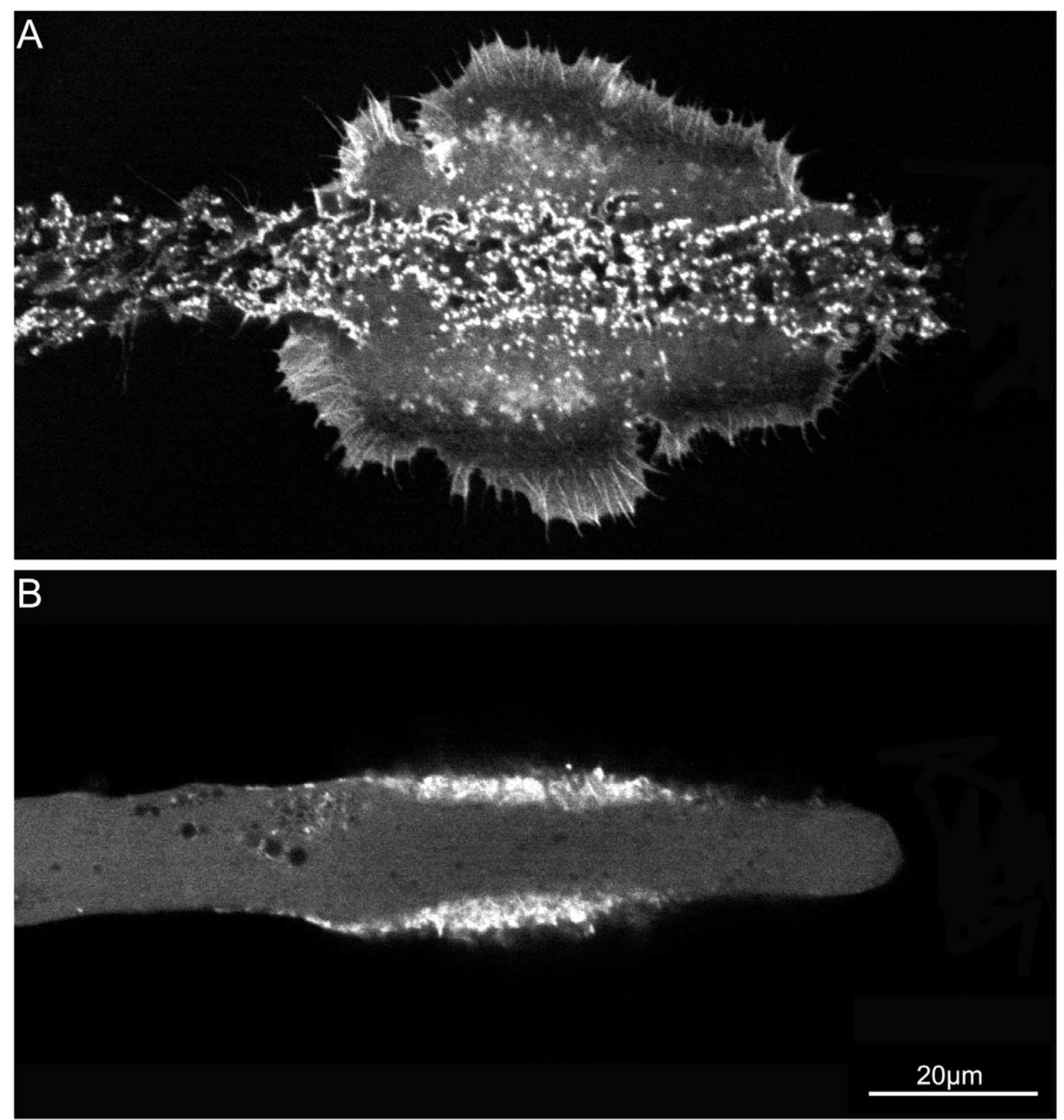

Fig. 2. EGFP-actin bundles at the leading edge of a growth cone lamellipodium formed after axotomy. A B1 neuron injected with mRNA encoding EGFP-actin fusion protein was axotomyzed $28 \mathrm{~h}$ later. Transection is followed by rapid extension of a growth cone's lamellipodium. (A) An image of the growth cone's lamellipodium taken at the level of the glass substrate 29 min after axotomy. (B) An image taken from the same region $3 \mu \mathrm{m}$ above the substrate. In A, actin puncta are seen along the axonal plasma membrane facing the substrate. The perimeters of the growth cone's lamellipodium contain radially oriented actin bundles. In B, $3 \mu \mathrm{m}$ above the substrate, the actin polymerise along the axon's plasma membrane. The core of the axoplasm does not contain clear actin network.

plating. For the injections $0.5-5 \mu \mathrm{g} / \mu \mathrm{l} \mathrm{mRNA}$ was prepared in $80 \mathrm{mM} \mathrm{KCl}$.

Injection was performed by pressure using Medical system Corp microinjector under visual control. We estimate the injected volume to be approximately $10 \%$ of the cell's body volume. The micropipette used for injection was also used to continuously monitor the trans membrane potential and input resistance (Benbassat and Spira, 1993). At the end of the injection the micropipette was gently pulled out of the cell. Injected cells were imaged for protein expression $12-48 \mathrm{~h}$ later.

\subsection{EGFP $m R N A$ injection}

To determine whether mRNA injection lead to successful and sufficient protein expression in cultured Aplysia neurones, in vitro transcribed mRNA encoding EGFP or EYFP were injected and examined 12-24 h 

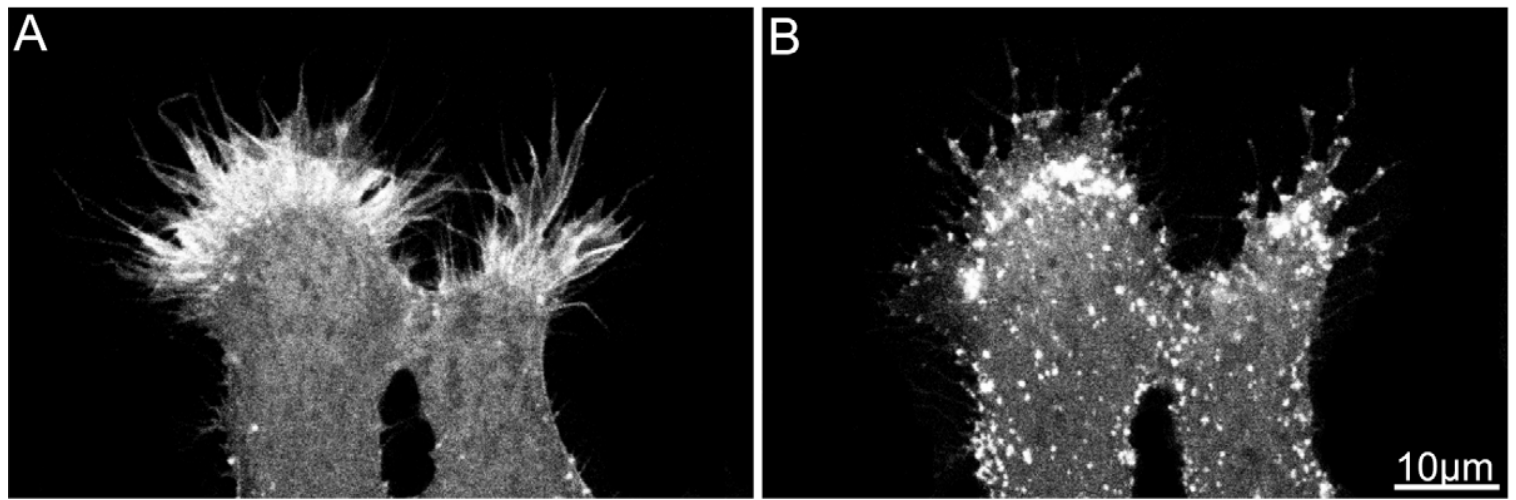

Fig. 3. Cytochalasin B induces disassembly of actin bundles at the leading edge of growth cones. Shown are two growth cones formed by a cultured B1 neuron injected with mRNA encoding EGFP-actin fusion protein. (A) The leading edges of the growth cones contain bundles of EGFP labelled actin. (B) Nine minutes after bath application of $2 \mu \mathrm{M}$ cytochalasin B the actin bundles disassemble and the dissociated actin form small aggregates within the collapsed growth cones and the axoplasm.

later. EGFP or EYFP expression was observed in close to $100 \%$ of the injected neurones within the cell body, the axons and neurites (Fig. 1). The fluorescent signal is evenly distributed in the cytoplasm.

\subsection{Expression of EGFP-fusion proteins}

Because of the particular interest that our laboratory have in visualising on-line cytoskeletal element restructuring and vesicle trafficking during growth cone formation, after mechanical injury of cultured Aplysia neurones (Ziv and Spira, 1995, 1997, 1998; Ashery et al., 1996; Spira et al., 1996, 2001, 2003; Gitler and Spira,
1998, 2002), we chose to demonstrate here the translational efficiency of the mRNAs encoding EGFP tagged actin and tubulin.

Injection of a solution containing mRNA encoding EGFP-actin fusion protein resulted in a high fluorescent signal in the cell body, axons, and neurites. The fluorescent signal appears to be distributed homogeneously in the cell body cytoplasm, main axon and neurites but is not detected within the nucleus. Fluorescent hot spots, most likely representing adhesion plaques, were seen along the plasma membrane facing the substrate. To determine whether the observed fluorescent signal corresponds to EGFP-tagged actin,
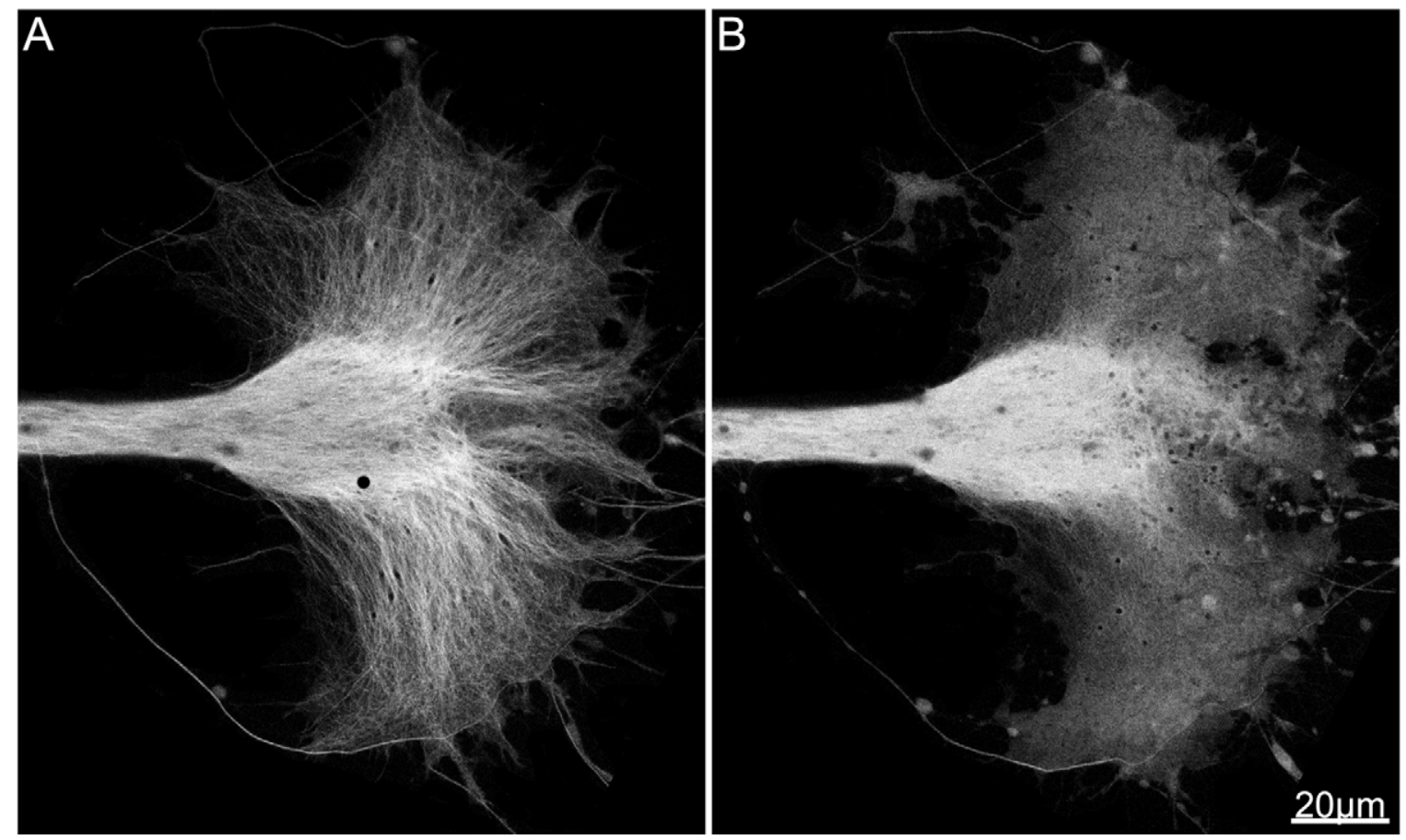

Fig. 4. Depolymerisation of microtubules within a growth cone formed after axotomy. A cultured B1 neuron injected with mRNA encoding EGFP at tubulin fusion protein. (A) EGFP labelled microtubules radiate from the growth cone centre towards the growth cone's lamellipodium perimeters. (B) Twenty three minutes after bath application of $5 \mu \mathrm{M}$ nocodosole the microtubules depolymerise. 
rather than EGFP alone the main axon was transected and the fluorescent signal distribution was imaged during the formation and extension of the growth cone's lamellipodium. Axonal transection of cultured Aplysia neuron leads to the rapid formation of a growth cone's lamellipodium at the tip of the cut axon (Ziv and Spira, 1995; Ashery et al., 1996; Gitler and Spira, 1998, 2002; Spira et al., 2001). It is well documented that the growth cone's lamellipodium perimeters are rich with actin filaments that are central to its motility (Forscher and Smith, 1988; Lin et al., 1994; Tanaka and Sabry, 1995; Scheafer et al., 2002).

Following axotomy of neurons injected with EGFPactin, a growth cone in the form of large lamellipodium is formed within 10-15 min of axotomy. The perimeters of the growth cone are rich with fluorescent actin bundles while the central region exhibit fluorescent puncta (Fig. 2). The fluorescent bundles depolymerise within minutes of cytochalasin B application (Fig. 3). Therefore, it is safe to assume that these bundles are EGFP labelled actin bundles. These results demonstrate that the fluorescent signal corresponds to expressed EGFP-actin fusion protein, which incorporates into the actin skeleton and allows the visualisation of the dynamic behaviour of this skeletal component.

\subsection{Expression of EGFP/EYFP-tagged microtubules and synaptic vesicle proteins}

To establish that the method described above can be used as a reliable tool to express various types of proteins in cultured Aplysia neurons we injected several other mRNAs encoding proteins tagged with either EGFP or EYFP. This included a tubulin and a member of the SNARE complex, the synaptosome associated protein of $25 \mathrm{kDa}$ (SNAP-25). On-line confocal microscope imaging of neurons injected by a solution containing mRNA encoding EGFP- $\alpha$ tubulin fusion protein resulted in incorporation of the tagged tubulin into microtubules that extended into an axotomy induced growth cone's lamellipodium (Fig. 4A). Bath application of the microtubules depolymerizing agent nocodazole $(5 \mu \mathrm{M})$ for 5 min resulted in depolymerisation of most microtubules (Fig. 4B).

The fluorescent signal of SNAP-25 revealed the presence of fluorescent spots in the intact axon as well as in the growth cone (not shown).

\section{Discussion}

In the present study we report the development of an efficient method for expression of GFP fusion proteins in cultured Aplysia neurons.

Functional genes have been expressed in Aplysia neurons following the injection of DNA plasmids
(Kaang, 1996a,b; Manseau et al., 2001; Lee et al., 2001), nevertheless, these proteins were expressed at low levels and visualised only within the domain of the cell body.

Attempts to express mRNA encoding the lacz, gene in Aplysia neurons were not very successful (Kaang, 1996a,b). Nevertheless, it is important to note that successful expression of mRNA encoding tetanus toxin (TeTx), and the light chain of botulinum neurotoxin (BoNT) has been reported already by Mochida et al. (1990). It is reasonable to assume that the positive results reported by these authors are due to the proteolytic nature of the toxins and the sensitive functional test to detect it. Thus, even very small amounts of expressed TeTx and BoTx are sufficient to totally block synaptic transmission.

The examples presented in Section 3 demonstrate the effectiveness of the procedures developed by us to express GFP fusion proteins in Aplysia neurons. Online imaging of the distribution of EGFP-tagged cytoskeletal elements, molecular motors, enzymes, kinases, lipases and other proteins are expected to facilitate the studies of fundamental mechanisms underlying various forms of neuroplasticity by the large community that uses Aplysia neurons as a model system.

\section{Acknowledgements}

This study was supported by grants from the Israel Science Foundation (No. 620/98), the US-IsraelBi-National Research Foundation (No. 97-00297-1) and the Charles E. Smith Family Laboratory for Collaborative Research in Psychobiology, the Hebrew University of Jerusalem. M.E. Spira is the Levi DeViali Professor in Neurobiology.

\section{References}

Ashery U, Penner R, Spira ME. Acceleration of membrane recycling by axotomy of cultured aplysia neurons. Neuron 1996;16:641-51.

Bailey CH, Kandel ER. Structural changes accompanying memory storage. Annu Rev Physiol 1993;55:397-426.

Baumann CT, Reyes IC. Tracking components of the transcription apparatus in living cells. Methods 1999;19:353-61.

Benbassat D, Spira ME. Survival of isolated axonal segments in culture: morphological, ultrastructural and physiological analysis. Exp Neurol 1993;122:295-310.

Chalfie M, Tu Y, Euskirchen G, Ward WW, Prasher DC. Green fluorescent protein as a marker for gene expression. Science 1994;263:802-5.

Chamberlain C, Hahn KM. Watching proteins in the wild: fluorescence methods to study protein dynamics in living cells. Traffic 2000;1:755-62

Day RN, Periasamy A, Schaufele F. Fluorescence resonance energy transfer microscopy of localized protein interactions in the living cell nucleus. Methods 2001;25:4-18. 
Ellenberg J, Lippincott SJ, Presley JF. Dual-colour imaging with GFP variants. Trends Cell Biol 1999;9:52-6.

Forscher P, Smith SJ. Actions of cytochalasins on the organization of actin filaments and microtubules in a neuronal growth cone. J Cell Biol 1988;107:1505-16.

Gerdes HH, Kaether C. Green fluorescent protein: applications in cell biology. FEBS Lett 1996;389:44-7.

Gitler D, Spira ME. Real time imaging of calcium-induced localized proteolytic activity after axotomy and its relation to growth cone formation. Neuron 1998;20:1123-35.

Gitler D, Spira ME. Short window of opportunity for calpain induced growth cone formation after axotomy of Aplysia neurons. J Neurobiol 2002;52:267-79.

Kaang BK. Parameters influencing ectopic gene expression in Aplysia neurons. Neurosci Lett 1996a;221:29-32.

Kaang BK. Neuronal expression of reporter genes in the intact nervous system of Aplysia. Mol Cell 1996b;6:285-95.

Kandel ER. The molecular biology of memory storage: a dialog between genes and synapses. Biosci Rep 2001a;21(5):565-611.

Kandel ER. The molecular biology of memory storage: a dialog between genes and synapses. Science 2001b;294:1030-8.

Kim HK, Kaang BK. Truncated green fluorescent protein mutants and their expression in Aplysia neurons. Brain Res Bull 1998;47:35-41.

Lee JA, Kim HK, Kim KH, Han JH, Lee YS, Lim CS, Chang DJ, Kubo T, Kaang BK. Overexpression of and RNA interference with the CCAAT enhancer-binding protein on long-term facilitation of Aplysia sensory to motor synapses. Learn Mem 2001;8:220-6.

Lin $\mathrm{CH}$, Thompson CA, Forscher P. Cytoskeletal reorganization underlying growth cone motility. Curr Opin Neurobiol 1994;4:640-7.

Lippincott SJ, Smith CL. Insights into secretory and endocytic membrane traffic using green fluorescent protein chimeras. Curr Opin Neurobiol 1997;7:631-9.

Manseau F, Fan X, Hueftlein T, Sossin W, Castellucci VF. Ca2+independent protein kinase C Apl II mediates the serotonininduced facilitation at depressed Aplysia sensorimotor synapses. J Neurosci 2001;21:1247-56.

Mochida S, Poulain B, Eisel U. Exogenous mRNA encoding tetanus or botulinum neurotoxins expressed in Aplysia neurons. Proc Natl Acad Sci USA 1990;87:7844-8.

Periasamy A, Day RN. Visualizing protein interactions in living cells using digitized GFP imaging and FRET microscopy. Methods Cell Biol 1999;58:293-314.

Rupp RAW, Snidel L, Weintraub H. Xenopus embryos regulate the nuclear localization of XmyoD. Genes Dev 1994;8:1311-23.

Schacher S, Proshansky E. Neurite regeneration by Aplysia neurons in dissociated cell culture: modulation by Aplysia hemolymph and the presence of the initial axonal segment. J Neurosci 1983;3:2403-13.
Scheafer AW, Kabir N, Forscher P. Filopodia and actin arcs guide the assembly and transport of two populations of microtubules with unique dynamic parameters in neuronal growth cone. J Cell Biol 2002;158(1):139-52.

Spergel DI, Kruth U, Shimshek DR, Sprengel R, Seeburg PH. Using reporter genes to label selected neuronal populations in transgenic mice for gene promotor, anatomical and physiological studies. Prog Neurobiol 2001;63:673-86.

Spira ME, Benhassat D, Dormann A. Resealing of the proximal and distal cut ends of transected axons: electrophysiological and ultrastructural analysis. J Neurobiol 1993;24:300-16.

Spira ME, Dormann A, Ashery U, Gabso M, Gitler D, Benbassat D, Oren R, Ziv NE. Use of Aplysia neurons for the study of cellular alterations and the resealing of transected axons in vitro. $\mathrm{J}$ Neurosci Methods 1996;69:91-102.

Spira ME, Oren R, Dormann A, Llouz N, Lev S. Calcium, protease activation and cytoskeleton remodeling underlie growth cone formation and neuronal regeneration. Cell Mol Neurobiol 2001;21(6)8:591-03.

Spira ME, Oren R, Dormann A, Gitler D. Critical calpain-dependent ultrastructural alterations underlie the transformation of an axonal segment into a growth cone after axotomy of cultured Aplysia neurons. J Comp Neurol 2003;457(3):293-312.

Stearns T. Green fluorescent protein. The green revolution. Curr Biol 1995;5:262-4.

Suter DM, Forscher P. Substrate-cytoskeletal coupling as a mechanism for the regulation of growth cone motility and guidance. $\mathbf{J}$ Neurobiol 2000;44:97-113.

Tanaka E, Sabry I. Making the connection: cytoskeletal rearrangements during growth cone guidance. Cell 1995;83:171-6.

Tsien RY. The green fluorescent protein. Annu Rev Biochem 1998;67:509-44.

Turner DL, Weintraub H. Expression of achaete-scute homolog 3 in Xenopus embryos converts ectodermal cells to a neural fate. Genes Dev 1994;8:1434-47.

Van Roessel P, Brand AH. Imaging into the future: visualizing gene expression and protein interactions with fluorescent proteins. Nat Cell Biol 2002;4:E15-20.

Ziv NE, Spira ME. Axotomy induces a transient and localized elevation of the free intracellular calcium concentration to the millimolar range. $\mathbf{J}$ Neurophysiol 1995;74:2625-37.

Ziv NE, Spira ME. Localized and transient elevations of intracellular $\mathrm{Ca} 2+$ induce the dedifferentiation of axonal segments into growth cones. J Neurosci 1997;17:3568-79.

Ziv NE, Spira ME. Induction of growth cone formation by transient and localized increases of intracellular proteolytic activity. J Cell Biol 1998;140:223-32. 